\title{
The Still Underestimated Problem of Fungal Diseases Worldwide
}

\author{
Fausto Almeida ${ }^{1 *}$, Marcio L. Rodrigues ${ }^{2,3}$ and Carolina Coelho ${ }^{4,5 *}$ \\ ${ }^{1}$ Department of Biochemistry and Immunology, Ribeirão Preto Medical School, University of São Paulo, Ribeirão Preto, \\ Brazil, ${ }^{2}$ Instituto Carlos Chagas, Fundação Oswaldo Cruz (Fiocruz), Curitiba, Brazil, ${ }^{3}$ Instituto de Microbiologia, Universidade \\ Federal do Rio de Janeiro, Rio de Janeiro, Brazil, ${ }^{4}$ Department of Molecular Microbiology and Immunology, Johns Hopkins \\ Bloomberg School of Public Health, Baltimore, MD, United States, ${ }^{5}$ Department of Biosciences, College of Life and \\ Environmental Sciences, University of Exeter, Exeter, United Kingdom
}

\section{OPEN ACCESS}

Edited by:

Agostinho Carvalho, University of Minho, Portugal

Reviewed by:

Praveen Rao Juvvadi, Duke University, United States Guillermo Quindós, University of the Basque Country, Spain

*Correspondence: Fausto Almeida fbralmeida@usp.br Carolina Coelho

c.coelho@exeter.ac.uk

Specialty section: This article was submitted to Fungi and Their Interactions,

a section of the journa

Frontiers in Microbiology

Received: 24 September 2018

Accepted: 25 January 2019

Published: 12 February 2019

Citation:

Almeida F, Rodrigues ML and

Coelho C (2019) The Still Underestimated Problem of Fungal

Diseases Worldwide.

Front. Microbiol. 10:214 doi: 10.3389/fmicb.2019.00214
In the past few years, fungal diseases caused estimated over 1.6 million deaths annually and over one billion people suffer from severe fungal diseases (Brown et al., 2012; Anonymous, 2017b). Public health surveillance of fungal diseases is generally not compulsory, suggesting that most estimates are conservative (Casadevall, 2017; Anonymous, 2017a). Fungal disease can also damage plants and crops, causing major losses in agricultural activities and food production (Savary et al., 2012). Animal pathogenic fungi are threatening bats, amphibians and reptiles with extinction (Casadevall, 2017). It is estimated that fungi are the highest threat for animal-host and plant-host species, representing the major cause (approximately 65\%) of pathogendriven host loss (Fisher et al., 2012). In this complex scenario, it is now clear that the global warming and accompanying climate changes have resulted in increased incidence of many fungal diseases (Garcia-Solache and Casadevall, 2010). On the basis of all these factors, concerns on the occurrence of a pandemic of fungal origin in a near future have been raised (Casadevall, 2017). In this context, to stop forgetting and underestimating fungal diseases is mandatory.

Keywords: fungal diseases, fungal infection, public health, fungal pathogen, fungi

\section{THE BURDEN OF HUMAN FUNGAL INFECTIONS}

Currently, there are few antifungal drugs approved for use in humans (Pianalto and Alspaugh, 2016). The last antifungals approved for human use were characterized in 2002. This scenario may be linked to an imbalance between funding and mortality rates in the field of fungal diseases (Rodrigues, 2016). For instance, cryptococcal meningitis results in approximately 180000 deaths annually globally (Rajasingham et al., 2017), as compared to 429000 deaths caused by malaria or 1.6 million tuberculosis-deaths (as estimated by WHO in 2015 and 2017, respectively). However, cryptococcosis received less than $0.5 \%$ of the global research and development funding, while malaria and tuberculosis received together $35.5 \%$ of the total investment in research and development in infectious diseases (Moran et al., 2015). Current therapeutic to treat fungal diseases remain unsatisfactory, and to develop novel therapeutic alternatives a significant investment in dedicated research is required (Coelho and Casadevall, 2016). Novel antifungal are in different 
clinical development stages, and these new compounds such as AR-12 (Baxter et al., 2011), BHBM (Mor et al., 2015), CD101 (Zhao et al., 2016), E1210/11 (Pfaller et al., 2011), F901318 (Wiederhold et al., 2017), Ilicicolin H (Singh et al., 2012), Nikkomycin Z (Hector et al., 1990), Sampangine (Agarwal et al., 2008), Scy-078 (Lepak et al., 2015), Sertraline (Zhai et al., 2012), T-2307 (Mitsuyama et al., 2008), Tamoxifen (Dolan et al., 2009), and VT-1129 (Douglas et al., 1994). Some of these (VT-119 and Nikkomycin Z, for example) belong to new classes of drugs, i.e., they act through different mechanisms and molecular targets than the already approved drugs, and may provide a much-needed extension to the limited therapies currently available. Programs specifically offering funding to mycological research are necessary to potentiate further development of effective antifungal therapy and ultimately reduce mortality from fungal diseases.

\section{THE IMPACT OF FUNGAL INFECTIONS ON FOOD CROPS AND DISPROPORTIONATE IMPACT IN DEVELOPING COUNTRIES}

Fungal diseases in developing countries demand special attention. Many of the fungal diseases in Latin America are often overlooked, although they clearly fulfill the criteria to be classified as neglected human diseases (Rodrigues, 2016, 2018). The general impact of fungal pathogens on human health goes beyond the ability of fungi to infect humans, since they destroy a third of all food crops annually (Fisher et al., 2012), causing economical loss and impacting global poverty. Statistics from the 2009-2010 world harvest (www.fao.org or FAOSTAT1) suggest fungi-induced losses in five of the most important crops globally (rice, wheat, maize, potatoes, and soybean). If those losses were mitigated, these crops would have been enough to feed $8.5 \%$ of the seven billion populations in 2011 (Fisher et al., 2012). Furthermore, in a hypothetical event where these five crops were affected simultaneously, approximately $61 \%$ of the world's population would not have food (Fisher et al., 2012). The most economically devastating fungi are Magnaporthe oryzae, affecting rice and wheat, followed by Botrytis cinerea, which has a broad host range and Puccinia spp., affecting wheat (Dean et al., 2012). Several high-value crops produced in the tropics, such as bananas, coffee, cacao, spices, mangos, and several nuts, are currently affected by fungal infections and these crops are not produced colder climates (Drenth and Guest, 2016). Therefore dependence of crop produced in tropical regions aggravated with a lack of biodefense and preparedness might result in disastrous economical consequences worldwide.

Fungal infections of invertebrate hosts may also impact agricultural crises due to ecological imbalance. For instance, bee broods are susceptible to fungal infections caused by genera of Ascosphaera and Aspergillus (Jensen et al., 2013), and the agricultural production worldwide is highly dependent on pollination mediated by bees (Aizen et al., 2009; Stein et al., 2017). Fungal infection of bees may precipitate a disaster (Bromenshenk et al., 2010), with unpreceded impact on agriculture and various plant species.

\section{THE IMPACT OF FUNGAL INFECTIONS ON ANIMAL SPECIES}

When fungi cause animal disease the outcomes are quite dramatic and scientists have been trying to raise attention to the effects of fungal infections in decreasing biodiversity, an effect aggravated (if not triggered) by global warming (Fisher et al., 2012; Seyedmousavi et al., 2018). Bat decimation caused by Geomyces destructans and several frog species by Batrachochytrium dendrobatidis are well known events. In invertebrates we already mentioned the case of bees, and further species may be affected but further research is needed. For example, there is a debate regarding if a marine Aspergillus spp. is associated with the decline of coral reefs (Kim and Harvell, 2004; Soler-Hurtado et al., 2016). Overall, the examples of species decimation in mammals, plants, and bees by fungal pathogens should prompt investigation of similar phenomenon in a wider scale, for example, other insects and in aquatic life.

\section{CRITICAL INTERACTIONS OF FUNGI WITH THE ENVIRONMENT}

It is important to highlight that most of the plant-fungal interactions are beneficial to both plants and fungi, with this symbiotic interaction improving plant growth, development, foraging, acquisition of soil resources, and tolerance to stress (Zeilinger et al., 2016). For instance, Trichoderma induces biofertilization of crops. The addition of Trichoderma hamatum or Trichoderma koningii to the production fields can increase crop productivity up to $300 \%$ (Benitez et al., 2004). Trichoderma spp. also acts in the mycoparasitism, the direct attack of one fungal species on another (Harman et al., 2004; Almeida et al., 2007), being described as potential biological control agent against important phytopathogenic fungi such as Fusarium spp., Rhizoctonia solani, Sclerotium rolfsii, Sclerotinia sclerotiorum, B. cinerea, and Pythium spp. (Zeilinger and Omann, 2007). Thus, mycoparasitism-based strategies could decrease the use of agrochemicals and antifungals in crop cultivation. In this sense, a better understanding of the fungal diversity and its impact on plant-fungal interactions would be highly beneficial to improve phytopathogen control.

\section{THE URGENCY OF COMBATTING FUNGAL INFECTIONS}

The reduced number of antifungals impact human health not only due to lack of therapy to cure human patients. Medically approved antifungal drugs have been used for agricultural purposes for decades (Azevedo et al., 2015). Most human pathogens have environmental niches, implying that 
TABLE 1 | Examples of important human mycoses.

\begin{tabular}{|c|c|c|}
\hline Fungal diseases & Distribution and etiological agent & Reference \\
\hline Aspergillosis & $\begin{array}{l}\text { Worldwide mycosis, caused by Aspergillus spp. Wide spectrum of infections in } \\
\text { humans, but mainly in immunocompromised individuals. There are more than } 250 \\
\text { species of Aspergillus, of these fewer than } 40 \text { are reported to cause infections in } \\
\text { humans. Aspergillus fumigatus and Aspergillus flavus are the most common } \\
\text { human pathogens. }\end{array}$ & Latge, 1999; Sugui et al., 2014 \\
\hline Blastomycosis & $\begin{array}{l}\text { Endemic mycosis located to the south central and north central United States, } \\
\text { caused by Blastomyces dermatitidis and Blastomyces gilchristii that can affects } \\
\text { immunocompetent and immunocompromised individuals. }\end{array}$ & Castillo et al., 2016; McBride et al., 2017 \\
\hline Candidiasis & $\begin{array}{l}\text { Worldwide mycosis, caused by Candida spp, a major cause of morbidity and } \\
\text { mortality worldwide, and the main causative agent in systemic fungal infections. } \\
\text { Among the Candida species, Candida albicans is the most common to cause } \\
\text { infections in humans. }\end{array}$ & Pfaller and Diekema, 2007; Yapar, 2014 \\
\hline Coccidioidomycosis & $\begin{array}{l}\text { Endemic to Southwestern United States and Central and South America, caused } \\
\text { by Coccidioides immitis and Coccidioides posadasii. }\end{array}$ & $\begin{array}{l}\text { Twarog and Thompson, 2015; Stockamp and } \\
\text { Thompson, } 2016\end{array}$ \\
\hline Cryptococcosis & $\begin{array}{l}\text { Wordlwide distribution, caused by Cryptococcus neoformans. Affects } \\
\text { immunocompromised hosts, and is a major cause of HIV-related deaths. One } \\
\text { noticeable outbreak in Vancouver Islands of } C \text {. gattii in immunocompetent patients. }\end{array}$ & $\begin{array}{l}\text { Casadevall and Perfect, 1998; Heitman et al., } \\
\text { 2011; Almeida et al., } 2015\end{array}$ \\
\hline Dermatophytosis & $\begin{array}{l}\text { Worldwide, Trichophyton rubrum and Trychophyton interdigitale have been } \\
\text { described as the most common to cause dermatophytosis, but many other } \\
\text { species contribute. The most frequent type of superficial mycosis in humans, } \\
\text { attacking skin and nails. }\end{array}$ & $\begin{array}{l}\text { Weitzman and Summerbell, 1995; Bitencourt } \\
\text { et al., 2018; Persinoti et al., } 2018\end{array}$ \\
\hline Histoplasmosis & $\begin{array}{l}\text { Worldwide?, Histoplasma capsulatum is the etiologic agent, mostly } \\
\text { immunocompromised individuals, it is one of the most common invasive fungal } \\
\text { pulmonary diseases. }\end{array}$ & Cano and Hajjeh, 2001; Guimaraes et al., 2006 \\
\hline Paracoccidiodomycosis & $\begin{array}{l}\text { Endemic to Latin America, caused by thermodimorphic fungi of the } \\
\text { Paracoccidioides species, is the most prevalent systemic mycosis in Latin America. }\end{array}$ & Colombo et al., 2011; Theodoro et al., 2012 \\
\hline Pneumocystis pneumonia & $\begin{array}{l}\text { Worldwide, caused by Pneumocystis jiroveci, affects patients that were } \\
\text { immunosuppressed, such as cancer patients receiving chemotherapy or HIV } \\
\text { patients. }\end{array}$ & $\begin{array}{l}\text { Thomas and Limper, 2004; Morris and Norris, } \\
2012\end{array}$ \\
\hline Sporotrichosis & $\begin{array}{l}\text { Worldwide, subcutaneous and subacute/chronic disease caused by dimorphic } \\
\text { fungus of the genus Sporothrix that affects humans and other mammals. }\end{array}$ & $\begin{array}{l}\text { Chakrabarti et al., 2015; Conceicao-Silva and } \\
\text { Morgado, } 2018\end{array}$ \\
\hline
\end{tabular}

the agricultural use of medically-approved drugs imposes the concrete risk of fostering drug resistance (Verweij et al., 2009; Zavrel and White, 2015). Emergence of antifungal resistance can endanger the already limited treatments options, with calamitous effects for treatment outcomes (Perlin et al., 2017). The development of new antifungal drugs is urgent to improve both human health and agricultural production.

The worsening of global warming opens a Pandora box for fungal diseases. Some thermally intolerant fungi with current pathogenic potential should acquire the ability to survive at mammalian temperatures (Garcia-Solache and Casadevall, 2010). This threat is heightened since some fungi can take advantage of a natural selection-adaptation strategy, and consequently to adapt to higher temperature by thermal selection (de Crecy et al., 2009; Panackal, 2011).

The collaboration between all these affected disciplines would be critical in facilitating at detecting epidemics early on and preventing further spread. The concept of One Health (King et al., 2008), with integration and communication between medical doctors, veterinarians, and food safety officials has been implemented with remarkable success and should become a standard for transmissible diseases (Ghosh et al., 2018). We have included a table summarizing basic information regarding distribution and etiological agent of important human mycoses (Table 1).
The negative impact of any infectious disease is usually higher in neglected populations. Lack of access to healthcare, underfunded healthcare, and delayed diagnosis lead to higher burden of fungal diseases. The economy of countries in developing countries strongly relies on agricultural production. Another fungal blight, if not managed properly, can still have disastrous economical and societal consequences.

The old adage "know your enemy" illustrates the major point of this essay: significant investment in fungal research, including fungal biology, human and plant pathogenicity, therapeutic agents, diagnostic tools, and vaccines, has the potential to avoid a global catastrophe. This call has been made by most, if not all, prominent fungal researchers (Molloy et al., 2017; Casadevall, 2018). We urge more attention to fungal biology and pathogenesis globally with special attention to diseases affecting developing countries, as a safeguard for prevention of losses in agriculture, environmental losses, and damage to human health.

\section{AUTHOR CONTRIBUTIONS}

All authors listed have made a substantial, direct and intellectual contribution to the work, and approved it for publication. 


\section{FUNDING}

FA acknowledged support from Fundação de Amparo a Pesquisa do Estado de São Paulo (2016/03322-7) and CNPq (Conselho Nacional de Desenvolvimento Científico e Tecnológico). MR is supported by the Brazilian agencies CAPES Coordenação de

\section{REFERENCES}

Agarwal, A. K., Xu, T., Jacob, M. R., Feng, Q., Lorenz, M. C., Walker, L. A., et al. (2008). Role of heme in the antifungal activity of the azaoxoaporphine alkaloid sampangine. Eukaryot. Cell 7, 387-400. doi: 10.1128/EC.00323-07

Aizen, M. A., Garibaldi, L. A., Cunningham, S. A., and Klein, A. M. (2009). How much does agriculture depend on pollinators? Lessons from long-term trends in crop production. Ann. Bot. 103, 1579-1588. doi: 10.1093/aob/mcp076

Almeida, F., Wolf, J. M., and Casadevall, A. (2015). Virulence-associated enzymes of Cryptococcus neoformans. Eukaryot. Cell 14, 1173-1185. doi: 10.1128/EC. 00103-15

Almeida, F. B., Cerqueira, F. M., Silva Rdo, N., Ulhoa, C. J., and Lima, A. L. (2007). Mycoparasitism studies of Trichoderma harzianum strains against Rhizoctonia solani: evaluation of coiling and hydrolytic enzyme production. Biotechnol. Lett. 29, 1189-1193. doi: 10.1007/s10529-007-9372-z

Anonymous (2017a). Stop neglecting fungi. Nat. Microbiol. 2:17120. doi: 10.1038/ nmicrobiol.2017.120

Anonymous (2017b). The Burden of Fungal Disease, on LIFE. Available at: http: //go.nature.com/2sMKpuN

Azevedo, M. M., Faria-Ramos, I., Cruz, L. C., Pina-Vaz, C., and Rodrigues, A. G. (2015). Genesis of azole antifungal resistance from agriculture to clinical settings. J. Agric. Food Chem. 63, 7463-7468. doi: 10.1021/acs.jafc.5b02728

Baxter, B. K., DiDone, L., Ogu, D., Schor, S., and Krysan, D. J. (2011). Identification, in vitro activity and mode of action of phosphoinositide-dependent-1 kinase inhibitors as antifungal molecules. ACS Chem. Biol. 6, 502-510. doi: 10.1021/ cb100399x

Benitez, T., Rincon, A. M., Limon, M. C., and Codon, A. C. (2004). Biocontrol mechanisms of Trichoderma strains. Int. Microbiol. 7, 249-260.

Bitencourt, T. A., Rezende, C. P., Quaresemin, N. R., Moreno, P., Hatanaka, O., Rossi, A., et al. (2018). Extracellular vesicles from the dermatophyte trichophyton interdigitale modulate macrophage and keratinocyte Functions. Front. Immunol. 9:2343. doi: 10.3389/fimmu.2018.02343

Bromenshenk, J. J., Henderson, C. B., Wick, C. H., Stanford, M. F., Zulich, A. W., Jabbour, R. E., et al. (2010). Iridovirus and microsporidian linked to honey bee colony decline. PLoS One 5:e13181. doi: 10.1371/journal.pone.0013181

Brown, G. D., Denning, D. W., Gow, N. A. R., Levitz, S. M., Netea, M. G., and White, T. C. (2012). Hidden killers: human fungal infections. Sci. Transl. Med. 4:165rv13. doi: 10.1126/scitranslmed.3004404

Cano, M. V., and Hajjeh, R. A. (2001). The epidemiology of histoplasmosis: a review. Semin. Respir. Infect. 16, 109-118. doi: 10.1053/srin.2001.24241

Casadevall, A. (2017). Don't forget the fungi when considering global catastrophic biorisks. Health Secur. 15, 341-342. doi: 10.1089/hs.2017.0048

Casadevall, A. (2018). Fungal diseases in the 21st century: the near and far horizons. Pathog. Immun. 3, 183-196. doi: 10.20411/pai.v3i2.249

Casadevall, A., and Perfect, J. R. (1998). Cryptococcus Neoformans. Washington, DC: ASM Press. doi: 10.1128/9781555818241

Castillo, C. G., Kauffman, C. A., and Miceli, M. H. (2016). Blastomycosis. Infect. Dis. Clin. North Am. 30, 247-264. doi: 10.1016/j.idc.2015.10.002

Chakrabarti, A., Bonifaz, A., Gutierrez-Galhardo, M. C., Mochizuki, T., and Li, S. (2015). Global epidemiology of sporotrichosis. Med. Mycol. 53, 3-14. doi: 10. 1093/mmy/myu062

Coelho, C., and Casadevall, A. (2016). Cryptococcal therapies and drug targets: the old, the new and the promising. Cell Microbiol. 18, 792-799. doi: 10.1111/cmi. 12590

Colombo, A. L., Tobon, A., Restrepo, A., Queiroz-Telles, F., and Nucci, M. (2011). Epidemiology of endemic systemic fungal infections in Latin America. Med. Mycol. 49, 785-798. doi: 10.3109/13693786.2011.577821

Conceicao-Silva, F., and Morgado, F. N. (2018). Immunopathogenesis of human sporotrichosis: what we already know. J. Fungi 4:E89. doi: 10.3390/jof4030089
Aperfeiçoamento de Pessoal de Nível Superior, Finance Code 001, CNPq and the Instituto Nacional de Ciência e Tecnologia de Inovação em Doenças de Populações Negligenciadas (INCTIDPN). MR is currently on a leave from a position of Associate Professor at Institute of Microbiology, Federal University of Rio de Janeiro, Brazil.

de Crecy, E., Jaronski, S., Lyons, B., Lyons, T. J., and Keyhani, N. O. (2009). Directed evolution of a filamentous fungus for thermotolerance. BMC Biotechnol. 9:74. doi: 10.1186/1472-6750-9-74

Dean, R., Van Kan, J. A., Pretorius, Z. A., Hammond-Kosack, K. E., Di Pietro, A., Spanu, P. D., et al. (2012). The Top 10 fungal pathogens in molecular plant pathology. Mol. Plant Pathol. 13, 414-430. doi: 10.1111/j.1364-3703.2011. 00783.x

Dolan, K., Montgomery, S., Buchheit, B., Didone, L., Wellington, M., and Krysan, D. J. (2009). Antifungal activity of tamoxifen: in vitro and in vivo activities and mechanistic characterization. Antimicrob. Agents Chemother. 53, 3337-3346. doi: 10.1128/AAC.01564-08

Douglas, C. M., Foor, F., Marrinan, J. A., Morin, N., Nielsen, J. B., Dahl, A. M., et al. (1994). The saccharomyces-cerevisiae Fks1 (Etg1) gene encodes an integral membrane-protein which is a subunit of 1,3-beta-D-glucan synthase. Proc. Natl. Acad. Sci. U.S.A. 91, 12907-12911. doi: 10.1073/pnas.91.26. 12907

Drenth, A., and Guest, D. I. (2016). Fungal and oomycete diseases of tropical tree fruit crops. Annu. Rev. Phytopathol. 54, 373-395. doi: 10.1146/annurev-phyto080615-095944

Fisher, M. C., Henk, D. A., Briggs, C. J., Brownstein, J. S., Madoff, L. C., McCraw, S. L., et al. (2012). Emerging fungal threats to animal, plant and ecosystem health. Nature 484, 186-194. doi: 10.1038/nature10947

Garcia-Solache, M. A., and Casadevall, A. (2010). Global warming will bring new fungal diseases for mammals. MBio 1:e00061-10. doi: 10.1128/mBio.00061-10

Ghosh, P. N., Fisher, M. C., and Bates, K. A. (2018). Diagnosing emerging fungal threats: a one health perspective. Front. Genet. 9:376. doi: 10.3389/fgene.2018. 00376

Guimaraes, A. J., Nosanchuk, J. D., and Zancope-Oliveira, R. M. (2006). Diagnosis of histoplasmosis. Braz. J. Microbiol. 37, 1-13. doi: 10.1590/S151783822006000100001

Harman, G. E., Howell, C. R., Viterbo, A., Chet, I., and Lorito, M. (2004). Trichoderma species - opportunistic, avirulent plant symbionts. Nat. Rev. Microbiol. 2, 43-56. doi: 10.1038/nrmicro797

Hector, R. F., Zimmer, B. L., and Pappagianis, D. (1990). Evaluation of nikkomycins $\mathrm{X}$ and $\mathrm{Z}$ in murine models of coccidioidomycosis, histoplasmosis, and blastomycosis. Antimicrob. Agents Chemother. 34, 587-593. doi: 10.1128/AAC. 34.4.587

Heitman, J., Kozel, T. R., Kwon-Chung, J., Perfect, J. R., and Casadevall, A. (2011). Cryptococcus: From Human Pathogen to Model Yeast. Washington, DC: ASM Press.

Jensen, A. B., Aronstein, K., Flores, J. M., Vojvodic, S., Palacio, M. A., and Spivak, M. (2013). Standard methods for fungal brood disease research. J. Apic. Res. 52, 1-39. doi: 10.3896/IBRA.1.52.1.13

Kim, K., and Harvell, C. D. (2004). The rise and fall of a six-year coral-fungal epizootic. Am. Nat. 164(Suppl. 5), S52-S63. doi: 10.1086/ 424609

King, L. J., Anderson, L. R., Blackmore, C. G., Blackwell, M. J., Lautner, E. A., Marcus, L. C., et al. (2008). Executive summary of the AVMA One health initiative task force report. J. Am. Vet. Med. Assoc. 233, 259-261. doi: 10.2460/ javma.233.2.259

Latge, J. P. (1999). Aspergillus fumigatus and aspergillosis. Clin. Microbiol. Rev. 12, 310-350. doi: 10.1128/CMR.12.2.310

Lepak, A. J., Marchillo, K., and Andes, D. R. (2015). Pharmacodynamic target evaluation of a novel oral glucan synthase inhibitor, SCY-078 (MK-3118), using an in vivo murine invasive candidiasis model. Antimicrob. Agents Chemother. 59, 1265-1272. doi: 10.1128/AAC.04445-14

McBride, J. A., Gauthier, G. M., and Klein, B. S. (2017). Clinical manifestations and treatment of blastomycosis. Clin. Chest. Med. 38, 435-449. doi: 10.1016/j.ccm. 2017.04.006 
Mitsuyama, J., Nomura, N., Hashimoto, K., Yamada, E., Nishikawa, H., Kaeriyama, M., et al. (2008). In vitro and in vivo antifungal activities of T2307, a novel arylamidine. Antimicrob. Agents Chemother. 52, 1318-1324. doi: 10.1128/AAC.01159-07

Molloy, S. F., Chiller, T., Greene, G. S., Burry, J., Govender, N. P., Kanyama, C., et al. (2017). Cryptococcal meningitis: a neglected NTD? PLoS Negl. Trop. Dis. 11:e0005575. doi: 10.1371/journal.pntd.0005575

Mor, V., Rella, A., Farnoud, A. M., Singh, A., Munshi, M., Bryan, A., et al. (2015). Identification of a new class of antifungals targeting the synthesis of fungal sphingolipids. MBio 6:e00647. doi: 10.1128/mBio.00647-15

Moran, M. C., Chapman, N., Abela-Oversteegen, L., Chowdhary, V., Doubell, A., Whittall, C., et al. (2015). G-FINDER: neglected disease research and developent: the ebola effect. Policy Cures 8, 13-85.

Morris, A., and Norris, K. A. (2012). Colonization by Pneumocystis jirovecii and its role in disease. Clin. Microbiol. Rev. 25, 297-317. doi: 10.1128/CMR.00013-12

Panackal, A. A. (2011). Global climate change and infectious diseases: invasive mycoses. J. Earth Sci. Clim. Chang. 2:108. doi: 10.4172/2157-7617.1000108

Perlin, D. S., Rautemaa-Richardson, R., and Alastruey-Izquierdo, A. (2017). The global problem of antifungal resistance: prevalence, mechanisms, and management. Lancet Infect. Dis. 17, e383-e392. doi: 10.1016/S1473-3099(17) 30316-X

Persinoti, G. F., Martinez, D. A., Li, W., Dogen, A., Billmyre, R. B., Averette, A., et al. (2018). Whole-genome analysis illustrates global clonal population structure of the ubiquitous dermatophyte pathogen Trichophyton rubrum. Genetics 208, 1657-1669. doi: 10.1534/genetics.117.300573

Pfaller, M. A., and Diekema, D. J. (2007). Epidemiology of invasive candidiasis: a persistent public health problem. Clin. Microbiol. Rev. 20, 133-163. doi: 10. 1128/CMR.00029-06

Pfaller, M. A., Duncanson, F., Messer, S. A., Moet, G. J., Jones, R. N., and Castanheira, M. (2011). In vitro activity of a novel broad-spectrum antifungal, E1210, tested against Aspergillus spp. determined by CLSI and EUCAST broth microdilution methods. Antimicrob. Agents Chemother. 55, 5155-5158. doi: 10.1128/AAC.00570-11

Pianalto, K. M., and Alspaugh, J. A. (2016). New horizons in antifungal therapy. J. Fungi 2:E26. doi: 10.3390/jof2040026

Rajasingham, R., Smith, R. M., Park, B. J., Jarvis, J. N., Govender, N. P., Chiller, T. M., et al. (2017). Global burden of disease of HIV-associated cryptococcal meningitis: an updated analysis. Lancet Infect. Dis. 17, 873-881. doi: 10.1016/ S1473-3099(17)30243-8

Rodrigues, M. L. (2016). Funding and innovation in diseases of neglected populations: the paradox of cryptococcal meningitis. PLoS Negl. Trop. Dis. 10:e0004429. doi: 10.1371/journal.pntd.0004429

Rodrigues, M. L. (2018). Neglected disease, neglected populations: the fight against Cryptococcus and cryptococcosis. Mem. Inst. Oswaldo Cruz 113:e180111. doi: 10.1590/0074-02760180111

Savary, S., Ficke, A., Aubertot, J. N., and Hollier, C. (2012). Crop losses due to diseases and their implications for global food production losses and food security. Food Secur. 4, 519-537. doi: 10.1007/s00203-017-1426-6

Seyedmousavi, S., Bosco, S. M. G., de Hoog, S., Ebel, F., Elad, D., Gomes, R. R., et al. (2018). Fungal infections in animals: a patchwork of different situations. Med. Mycol. 56, 165-187. doi: 10.1093/mmy/myx104

Singh, S. B., Liu, W., Li, X., Chen, T., Shafiee, A., Card, D., et al. (2012). Antifungal spectrum, in vivo efficacy, and structure-activity relationship of ilicicolin h. ACS Med. Chem. Lett. 3, 814-817. doi: 10.1021/ml300173e

Soler-Hurtado, M. M., Sandoval-Sierra, J. V., Machordom, A., and DieguezUribeondo, J. (2016). Aspergillus sydowii and other potential fungal pathogens in gorgonian octocorals of the ecuadorian pacific. PLoS One 11:e0165992. doi: 10.1371/journal.pone.0165992

Stein, K., Coulibaly, D., Stenchly, K., Goetze, D., Porembski, S., Lindner, A., et al. (2017). Bee pollination increases yield quantity and quality of cash crops in Burkina Faso, West Africa. Sci. Rep. 7:17691. doi: 10.1038/s41598-017-17970-2 Stockamp, N. W., and Thompson, G. R. III (2016). Coccidioidomycosis. Infect. Dis. Clin. North Am. 30, 229-246. doi: 10.1016/j.idc.2015.10.008

Sugui, J. A., Kwon-Chung, K. J., Juvvadi, P. R., Latge, J. P., and Steinbach, W. J. (2014). Aspergillus fumigatus and related species. Cold Spring Harb. Perspect. Med. 5, a019786. doi: 10.1101/cshperspect.a019786

Theodoro, R. C., Teixeira, M. D., Felipe, M. S. S., Paduan, K. D., Ribolla, P. M., San-Blas, G., et al. (2012). Genus paracoccidioides: species recognition and biogeographic aspects. PLoS One 7:e37694. doi: 10.1371/journal.pone.0037694

Thomas, C. F. Jr., and Limper, A. H. (2004). Pneumocystis pneumonia. N. Engl. J. Med. 350, 2487-2498. doi: 10.1056/NEJMra032588

Twarog, M., and Thompson, G. R. III (2015). Coccidioidomycosis: recent updates. Semin. Respir. Crit. Care Med. 36, 746-755. doi: 10.1055/s-0035-1562900

Verweij, P. E., Snelders, E., Kema, G. H., Mellado, E., and Melchers, W. J. (2009). Azole resistance in Aspergillus fumigatus: a side-effect of environmental fungicide use? Lancet Infect. Dis. 9, 789-795. doi: 10.1016/S1473-3099(09) 70265-8

Weitzman, I., and Summerbell, R. C. (1995). The dermatophytes. Clin. Microbiol. Rev. 8, 240-259. doi: 10.1128/CMR.8.2.240

Wiederhold, N. P., Law, D., and Birch, M. (2017). Dihydroorotate dehydrogenase inhibitor F901318 has potent in vitro activity against Scedosporium species and Lomentospora prolificans. J. Antimicrob. Chemother. 72, 1977-1980. doi: $10.1093 / \mathrm{jac} / \mathrm{dkx} 065$

Yapar, N. (2014). Epidemiology and risk factors for invasive candidiasis. Ther. Clin. Risk Manag. 10, 95-105. doi: 10.2147/TCRM.S40160

Zavrel, M., and White, T. C. (2015). Medically important fungi respond to azole drugs: an update. Future Microbiol. 10, 1355-1373. doi: 10.2217/FMB.15.47

Zeilinger, S., Gupta, V. K., Dahms, T. E., Silva, R. N., Singh, H. B., Upadhyay, R. S., et al. (2016). Friends or foes? Emerging insights from fungal interactions with plants. FEMS Microbiol. Rev. 40, 182-207. doi: 10.1093/femsre/fuv045

Zeilinger, S., and Omann, M. (2007). Trichoderma biocontrol: signal transduction pathways involved in host sensing and mycoparasitism. Gene Regul. Syst. Bio. 1, 227-234. doi: 10.4137/GRSB.S397

Zhai, B., Wu, C., Wang, L., Sachs, M. S., and Lin, X. (2012). The antidepressant sertraline provides a promising therapeutic option for neurotropic cryptococcal infections. Antimicrob. Agents Chemother. 56, 3758-3766. doi: 10.1128/AAC. 00212-12

Zhao, Y., Perez, W. B., Jimenez-Ortigosa, C., Hough, G., Locke, J. B., Ong, V., et al. (2016). CD101: a novel long-acting echinocandin. Cell Microbiol. 18, 1308-1316. doi: $10.1111 / \mathrm{cmi} .12640$

Conflict of Interest Statement: The authors declare that the research was conducted in the absence of any commercial or financial relationships that could be construed as a potential conflict of interest.

Copyright (C) 2019 Almeida, Rodrigues and Coelho. This is an open-access article distributed under the terms of the Creative Commons Attribution License (CC BY). The use, distribution or reproduction in other forums is permitted, provided the original author(s) and the copyright owner(s) are credited and that the original publication in this journal is cited, in accordance with accepted academic practice. No use, distribution or reproduction is permitted which does not comply with these terms. 